\title{
Enterprise Business Model Innovation in E-Commerce Environment
}

\author{
Zhenjie LONG $^{1}$, Fan PAN ${ }^{2}$ \\ ${ }^{1}$ School of Business, Guilin University of Electronic Technology, Guangxi Province, 541004, China \\ ${ }^{2}$ School of Business, Guilin University of Electronic Technology, Guangxi Province, 541004, China \\ 346408988@qq.com,849687216@qq.com
}

\begin{abstract}
In the face of increasingly serious resource constraints and the growing prosperity of e-commerce environment, the business model has become the focus of market competition. The study of the business model can lay the foundation for innovation. Therefore, the article analyzes the structural relationship of business model among its influence factors based on the interpretative structural model. We can explore the mechanism of business model innovation, so as to provide a reference for our enterprise business model innovation.

Index Terms - e-commerce; Business model; Business model innovation; Interpretative structural model
\end{abstract}

\section{Introduction}

Business model innovation plays a more and more important role in the development of enterprises. Under the highly competitive environment, reducing the place and the cost, DELL was the first to direct sales through the Internet and improved the market share in the serious homogenization of the notebook market. With a strong combination of software, hardware and services platform, Apple Corp became a leader in mobile phone market. Such great success is owing to the business model innovation which has become one of the most popular topics in the industry and academia. Scholars have devoted to the study of business model innovation, in order to find out a better model and method to guide enterprises to carry out a successful business model innovation.

Although business model innovation has a decisive effect on the long-term success or failure of enterprises, many scholars have studied the mechanism of business model innovation from different perspectives. However, we still know little about it except product innovation. Therefore, based on the analysis of domestic and foreign scholars on business model innovation, the author summarizes and analyzes the elements of the business model, in order to find out the structural relationship between the major factors of the business model, explore the ways of enterprise business model innovation and provide a reference for the domestic enterprises' business model innovation.

\section{Definition and Composition of Business Model}

Business model, which first appearance was in the 1950s, is widely used and spread after the 1990s and also extended to the vast space in the field of business management. At present, we often refer to the business model of B2B mode, B2C mode, electronic market mode, auction mode, the mouse and cement mode, etc., but these are not the strict sense of the business model. Li Zhengyong (2009) based on a number of scholars' researches about the business model, proposed that business model was to ensure the maximized value of the customer, through the integration of various elements of the enterprise to form a complete, interest related, external difficult to imitate and a unique core competitiveness of the operating system. Finally, a better business model should not only make the customers satisfied, but also ensure the system to achieve sustainable profitability solutions.

Business model and innovation are closely related, while innovation is the inherent nature of the business model. Davila, Epstein and Shelton (2005) proposed that business model innovation was realized by the innovation of the elements. Eisert \& Gassmann (2012) defined the business model innovation as the core elements of the enterprise and the process of the business logic. They thought that the business model innovation had a decisive role in the long-term success or failure of the enterprise. To better understand the business model, Baden-Fuller \& Morgan (2010) believe that only the elements of the business model are not enough. People need to further know the elements of the business model and the relationship among them (Casadesus - Masanell \& Ricart (2010)). Therefore, this paper starts with the elements of the business model, uses Interpretative Structural Model(ISM) for the qualitative analysis, aims to establish a hierarchical structure model for the elements of the business model, clarifies the logical relationship between the elements of the business model, and identified the business model in order to design its own business model.

The researches on business model elements have different views as a result of scholars have different definitions of business model. Now the representative business model is Ostenwalder (2005) proposed, that is, value proposition, market segmentation, marketing channel, customer relationship, revenue source, core competence, resource allocation, cooperative partners and cost structure.

\section{Establish the Interpretative Structural Model (ISM)}

Interpretative structure model (ISM) is developed a system analysis method by J. huafer professor in 1973, and based on qualitative analysis, which belongs to the conceptual model. Its characteristics are to use people's experience and knowledge as well as the help of computer to transform ambiguous views into a multi-level hierarchical structure model, which has some structure relations. It was used to analyzing the system which had many variables and complex relationships each other. Its running steps composed of the 
selection of members, setting up the problem, the relationship among the elements and the interpretation of the structure model. While the construction of the structure model included the establishment of the adjacency matrix, the formation of the reachable matrix, the level of the elements and the hierarchical structure.

The members of this research come from the Guilin University of Electronic Technology Business School professor, business management professional graduate students and MBA students. Through the analysis of the group members, the descriptive definition of the elements of business model and the correlation between them are shown in Table 1.

TABLE I Descriptive Definitions of the Elements of Business Model

\begin{tabular}{|c|c|c|c|}
\hline NO. & $\begin{array}{l}\text { the elements } \\
\text { of business } \\
\text { model }\end{array}$ & descriptive definitions & $\begin{array}{l}\text { direct } \\
\text { acting } \\
\text { factor }\end{array}$ \\
\hline $\mathrm{S}_{1}$ & $\begin{array}{l}\text { value } \\
\text { proposition }\end{array}$ & $\begin{array}{l}\text { How companies will create the value } \\
\text { of the target market differentiation, as } \\
\text { well as to occupy what position in the } \\
\text { target market }\end{array}$ & $\mathrm{S}_{4}$ \\
\hline $\mathrm{S}_{2}$ & $\begin{array}{l}\text { market } \\
\text { segmentation }\end{array}$ & $\begin{array}{l}\text { The market is divided into smaller } \\
\text { groups of customers, these customers } \\
\text { have different needs, characteristics } \\
\text { or behavior, need different marketing } \\
\text { strategies or combinations }\end{array}$ & $\begin{array}{l}\mathrm{S}_{1}, \mathrm{~S}_{3} \\
\mathrm{~S}_{4}\end{array}$ \\
\hline $\mathrm{S}_{3}$ & $\begin{array}{l}\text { marketing } \\
\text { channel }\end{array}$ & $\begin{array}{l}\text { Constituted by a series of independent } \\
\text { organizations, through the assistance } \\
\text { of these organizations, so that } \\
\text { products or services for consumer } \\
\text { spending or business users }\end{array}$ & $\mathrm{S}_{4}$ \\
\hline $\mathrm{S}_{4}$ & $\begin{array}{l}\text { customer } \\
\text { relationship }\end{array}$ & $\begin{array}{l}\text { The connection between the } \\
\text { enterprise and its consumer group }\end{array}$ & \\
\hline $\mathrm{S}_{5}$ & $\begin{array}{l}\text { revenue } \\
\text { source }\end{array}$ & $\begin{array}{l}\text { Enterprise through the integration of } \\
\text { their own and the relevant } \\
\text { stakeholders and the formation of a } \\
\text { value creation, the value of the } \\
\text { organization and the interests of the } \\
\text { organization and business framework }\end{array}$ & $\mathrm{S}_{1}, \mathrm{~S}_{6}$ \\
\hline $\mathrm{S}_{6}$ & $\begin{array}{l}\text { core } \\
\text { competence }\end{array}$ & $\begin{array}{l}\text { The main capacity of the enterprise, } \\
\text { in the competition of the dominant } \\
\text { position in the hands of the strength, } \\
\text { is difficult to meet the other } \\
\text { competitors, or unable to have a } \\
\text { capacity }\end{array}$ & $\mathrm{S}_{1}, \mathrm{~S}_{2}$ \\
\hline $\mathrm{S}_{7}$ & $\begin{array}{l}\text { resource } \\
\text { allocation }\end{array}$ & $\begin{array}{l}\text { Allocation of resources and activities } \\
\text { of the company }\end{array}$ & $\begin{array}{l}\mathrm{S}_{2}, \mathrm{~S}_{3} \\
\mathrm{~S}_{4}, \mathrm{~S}_{8} \\
\end{array}$ \\
\hline $\mathrm{S}_{8}$ & $\begin{array}{l}\text { cooperative } \\
\text { partners }\end{array}$ & $\begin{array}{l}\text { A partnership with other people in the } \\
\text { company, the process of creating and } \\
\text { delivering more value for customers. }\end{array}$ & $\mathrm{S}_{3}$ \\
\hline $\mathrm{S}_{9}$ & cost structure & $\begin{array}{l}\text { Analysis of the various components } \\
\text { of the operating cost of the enterprise } \\
\text { and the cost of the project, in order to } \\
\text { find the way to further reduce the } \\
\text { cost. }\end{array}$ & $\begin{array}{l}\mathrm{S}_{3}, \mathrm{~S}_{7}, \\
\mathrm{~S}_{8}\end{array}$ \\
\hline
\end{tabular}

\subsection{Establish the adjacency matrix and reachable matrix}

According to the correlation of the elements in Table 2, the adjacency matrix $\mathrm{A}$ is established. The elements of the matrix elements $S_{i}$ and $S_{j}$, if $S_{i}$ has a direct impact on $S_{j}, a_{i j}=1$, which shows that the elements $S_{i}$ and $S_{j}$ have something relationship. That is, $\mathrm{S}_{\mathrm{i}} \mathrm{RS}_{\mathrm{j}}$. In other situations, $\mathrm{a}_{\mathrm{ij}}=0$, indicates that the elements $S_{i}$ and $S_{j}$ have no relationship. That is, $S_{i} R S_{j}$. The adjacency matrix only reflects the direct relationship between the elements, and the indirect relationship between them can be expressed by the matrix R. Using Boolean algebra, the $n$ power operation is done on $\mathrm{A}+\mathrm{I}$, until the following equation is established, and a positive integer $\mathrm{n}$ is obtained.

$(\mathrm{A}+\mathrm{I})^{1} \neq(\mathrm{A}+\mathrm{I})^{2} \neq \ldots \neq \ldots(\mathrm{A}+\mathrm{I})^{\mathrm{n}}=(\mathrm{A}+\mathrm{I})^{\mathrm{n}+1}=\mathrm{R}$

Matrix $\mathrm{R}$ is called the reachable matrix. This experiment uses Boolean algebra to do 3 power operations, namely $(\mathrm{A}+\mathrm{I})^{1} \neq(\mathrm{A}+\mathrm{I})^{2}=(\mathrm{A}+\mathrm{I})^{3}$, and finally get the matrix $\mathrm{R}=(\mathrm{A}+\mathrm{I})^{2}$, as follows:

$\mathrm{A}=\left[\begin{array}{l|l|l|l|l|l|l|l|l}0 & 0 & 0 & 1 & 0 & 0 & 0 & 0 & 0 \\ \hline 1 & 0 & 1 & 1 & 0 & 0 & 0 & 0 & 0 \\ \hline 0 & 0 & 0 & 1 & 0 & 0 & 0 & 0 & 0 \\ 0 & 0 & 0 & 0 & 0 & 0 & 0 & 0 & 0 \\ \hline 1 & 0 & 0 & 0 & 0 & 1 & 0 & 0 & 0 \\ \hline 1 & 1 & 0 & 0 & 0 & 0 & 0 & 0 & 0 \\ \hline 0 & 1 & 1 & 1 & 0 & 0 & 0 & 1 & 0 \\ 0 & 0 & 1 & 0 & 0 & 0 & 0 & 0 & 0 \\ 0 & 0 & 1 & 0 & 0 & 0 & 1 & 1 & 0\end{array}\right]$

$\mathrm{R}=\left[\begin{array}{l|l|l|l|l|l|l|l|l}1 & 0 & 0 & 1 & 0 & 0 & 0 & 0 & 0 \\ \hline 1 & 1 & 1 & 1 & 0 & 0 & 0 & 0 & 0 \\ \hline 0 & 0 & 1 & 1 & 0 & 0 & 0 & 0 & 0 \\ \hline 0 & 0 & 0 & 1 & 0 & 0 & 0 & 0 & 0 \\ \hline 1 & 1 & 1 & 1 & 1 & 1 & 0 & 0 & 0 \\ \hline 1 & 1 & 1 & 1 & 0 & 1 & 0 & 0 & 0 \\ \hline 1 & 1 & 1 & 1 & 0 & 0 & 1 & 1 & 0 \\ \hline 0 & 0 & 1 & 1 & 0 & 0 & 0 & 1 & 0 \\ \hline 1 & 1 & 1 & 1 & 0 & 0 & 1 & 1 & 1\end{array}\right]$

\section{2the regional division and the class division of the reachable matrix}

Regional division is to divide the relationship between the elements into up and not up, and to determine which elements are connected, that is, the system is divided into several parts and sub sections. First, the reachable sets $\mathrm{R}\left(\mathrm{S}_{\mathrm{i}}\right)\left(\mathrm{R}\left(\mathrm{S}_{\mathrm{i}}\right)=\left\{\mathrm{S}_{\mathrm{i}} \in \mathrm{N} \mid \mathrm{M}_{\mathrm{ij}}=1\right\}\right) \quad$ and antecedent sets $\mathrm{A}\left(\mathrm{S}_{\mathrm{j}}\right)\left(\mathrm{A}\left(\mathrm{S}_{\mathrm{i}}\right)=\left\{\mathrm{S}_{\mathrm{j}} \in \mathrm{N} \mid \mathrm{M}_{\mathrm{ji}}=1\right\}\right)$ of the reachable matrix, then calculate $R\left(S_{i}\right) \cap A\left(S_{i}\right)$, we can get common sets $T\left(T=\left\{S_{j}\right.\right.$ $\left.\left.\in \mathrm{N} \mid \mathrm{R}\left(\mathrm{S}_{\mathrm{i}}\right) \cap \mathrm{A}\left(\mathrm{S}_{\mathrm{i}}\right)=\mathrm{A}\left(\mathrm{S}_{\mathrm{i}}\right)\right\}\right)$, namely, the collection of the underlying elements. For the common set of elements, if the elements $\mathrm{Si}$ and $\mathrm{Sj}$ belong to the same connected domain, then they must have a common unit, $\mathrm{R}\left(\mathrm{S}_{\mathrm{i})} \cap \mathrm{R}\left(\mathrm{S}_{\mathrm{j}}\right) \neq \phi\right.$. If $\phi$, they are divided into two connected domains. Therefore, in the actual system analysis, if there are two or more than two connected domain, it needs to restudy the relationship is correct. Level division is to divide all the elements of the system into different levels. Firstly, the definition of the most advanced collection analysis of multi-level structure of the advanced elements, after confirming the most advanced elements, in the reachable matrix delimits the advanced elements of the rows and columns. And then, with the same method, the remaining reachable matrix continues to search for the most advanced elements. And so on, you can find out the set of elements contained in the highest levels. If L1, L2,.. Lk, said the order 
from top to bottom, there is a system of $\mathrm{K}$ level, $\mathrm{L}(\mathrm{n})$ can be expressed as $\mathrm{L}(\mathrm{n})=\left[\mathrm{L}_{1}, \mathrm{~L}_{2}, \ldots, \mathrm{L}_{\mathrm{k}}\right]$.

According to the reachable matrix $\mathrm{R}$, we can get the reachable set, the first set and the common set, as shown in table 2:

TABLE 2 The First Reachable Set And The First Set

\begin{tabular}{|c|c|c|c|}
\hline $\mathrm{S}_{\mathrm{i}}$ & $\mathrm{R}\left(\mathrm{S}_{\mathrm{i}}\right)$ & $\mathrm{A}\left(\mathrm{S}_{\mathrm{i}}\right)$ & $\mathrm{R}\left(\mathrm{S}_{\mathrm{i}}\right) \cap \mathrm{A}\left(\mathrm{S}_{\mathrm{i}}\right)$ \\
\hline $\mathrm{S}_{1}$ & 1,4 & $1,2,5,6,7,9$ & 1 \\
\hline $\mathrm{S}_{2}$ & $1,2,3,4$ & $2,5,6,7,9$ & 2 \\
\hline $\mathrm{S}_{3}$ & 3,4 & $2,3,5,6,7,8,9$ & 3 \\
\hline $\mathrm{S}_{4}$ & 4 & $1,2,3,4,5,6,7,8,9$ & 4 \\
\hline $\mathrm{S}_{5}$ & $1,2,3,4,5,6$ & 5 & 5 \\
\hline $\mathrm{S}_{6}$ & $1,2,3,4,6$ & 5,6 & 6 \\
\hline $\mathrm{S}_{7}$ & $1,2,3,4,7,8$ & 7,9 & 7 \\
\hline $\mathrm{S}_{8}$ & $3,4,8$ & $7,8,9$ & 8 \\
\hline $\mathrm{S}_{9}$ & $1,2,3,4,7,8,9$ & 9 & 9 \\
\hline
\end{tabular}

From table 3, we can see common set $\mathrm{T}=\{5,9\}$. $\mathrm{R}$ (5) $\cap \mathrm{R}(9) \neq \phi$, therefore, there is only one system of connected domains. By the formula: $R\left(S_{i}\right) \cap A\left(S_{i}\right)=R\left(S_{i}\right)$, the first highest level elements for $S_{4}$. That is: $L 1=\{S 4\}$, we remove the highest elements of the fourth elements and fourth columns in the R matrix, after finding out the senior elements. Then, looking for the new element, we could find the second

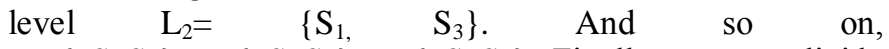
$\mathrm{L}_{3}=\left\{\mathrm{S}_{2}, \mathrm{~S}_{8}\right\}, \mathrm{L}_{4}=\left\{\mathrm{S}_{6}, \mathrm{~S}_{7}\right\}, \mathrm{L}_{5}=\left\{\mathrm{S}_{5}, \mathrm{~S}_{9}\right\}$, Finally, we can divide the business model elements into five grades from top to bottom in turn.

\subsection{Establish a hierarchical structure model}

Through regional division and class division of the reachable matrix, we can establish the structure model, use the corresponding factors name instead, finally get multilayer hierarchical interpretative structural model of the business model constitute elements, as shown in Figure 1 and 2:

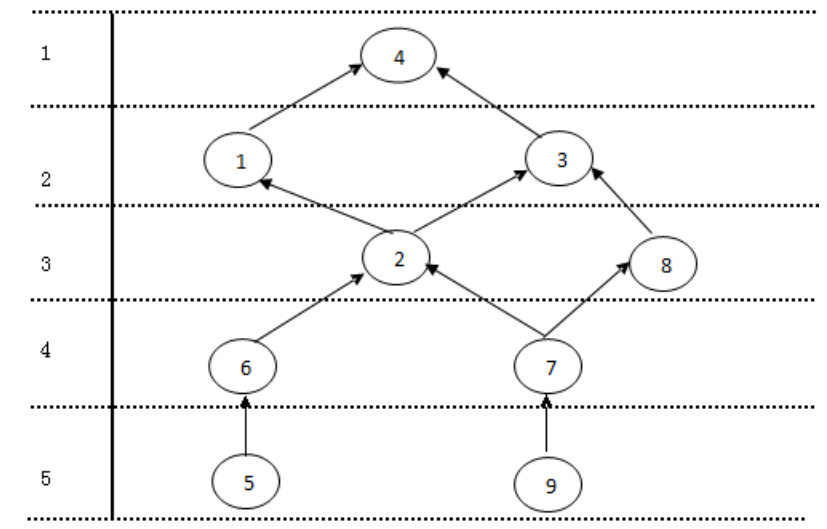

Fig. 1 Structure hierarchical directed graph about the elements of business mode

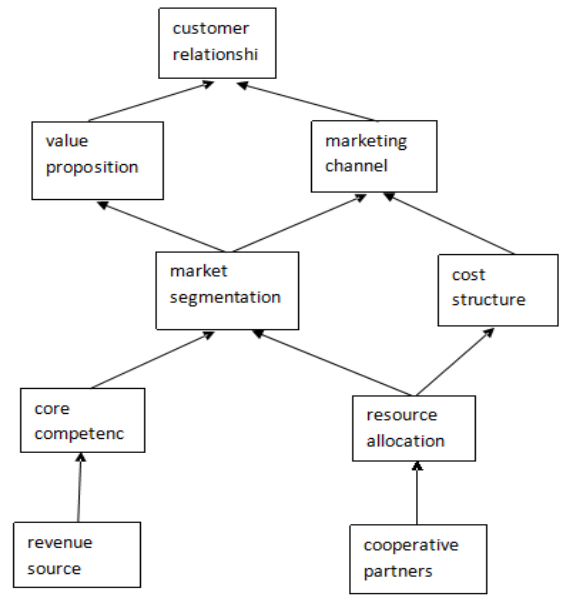

Fig. 2 Hierarchical interpretative structure model about the elements of business mode

\section{ISM Analysis of Business Models}

According to the business model shown in Figure 2, the composition of the business model is divided into 5 levels. In this system, the position of each component as follows:

First, the bottom of the system is revenue source and cost structure. They are the key to the operation of the business model, but also the most basic part of the whole system. Revenue source and cost structure reflect the company how to realize the products and services that they want to provide, while business income source is included in the business cost, the profit can be ensured finally, and the normal operation of the enterprise can also be ensured. So they are the most basic of the ISM and the breakthrough in business model innovation.

Secondly, market segmentation and cooperation partners in the third tier, the company through the discovery of consumer demands of the market segments, identify themselves to provide customers with products and services that better meet customers' needs, and lay the foundation of realizing value proposition. Enterprises should also pay attention to the full use of external resources to handle the relationship with other partners, market segmentation and other partners decided that brings the product or service to the customer, to lay the foundation for the value proposition and marketing channels. These are the center competence of enterprises and the whole value of the network resources optimization allocation.

Thirdly, the second level is the enterprise's value proposition and marketing channel, which belongs to the middle of the system. Value proposition is the unique value of the product and service that the company claims to be. It is the sum of a series of vested interests that the customer can perceive. Enterprises through market segmentation, can select target market to provide customers with a better value proposition. So value proposition and marketing channel are the key factor of business model innovation.

Finally, to maintain a good relationship with customers is the surface factor of the business model innovation and the goal of business model. In general, the innovation of enterprise business model should regard the customer as the 
center, be based on the Normal operation of Finance, adjust and optimize the allocation of resources, create a variety of contacts with the concept of double-win cooperation, constantly think their own business model, choose the right way to adjust the business model, and finally get a sustained competitive advantage.

\section{Conclusions}

Using ISM to analyze the factors of the business model, we can clearly see the interaction among the elements, help enterprises to further understand the business model. From the point of view of business model, we should know the following points: First, the business model is a system, which is the essential factor of business model, which means that the customer relationship, value proposition, marketing channel etc., to achieve new breakthroughs, and ultimately a systematic change.Second, the enterprise is not an independent individual, but the center node in the social network. If enterprises want to innovate the business model, it should be transformed a simple pursuit of profit from the closed system into a set of internal and external environment, resources and consumers in one of the open platform system, the enterprise itself is the core of the business ecosystem. Finally, the enterprise can build the competitive advantage of the system through the business model innovation.Therefore, for the enterprise, it needs to review the changes of their resources and the structure of the surrounding business network, and to take effective mode of innovation and enhance the competitiveness of enterprises. Only those enterprises who can continue to innovate and keep fit between the business model and business network can constantly continue to grow and develop.

\section{Reference}

[1] Li Zhengyong. Business logic - successful business model design guide. Beijing: The magazine Of Chinese Water Conservancy and Hydropower, 2009.

[2] Davila, T, Epstein, M, Shelton, R. Making innovation work: how to manage it, measure it and profit from it. NJ; Wharton School Pub, 2005: 29-58.

[3] Bucherer, E., Eisert, U., Gassmann, O.Towards Systematic Business Model Innovation: Lessons from Product Innovation Management. Creativity and Innovation Management, 2012, 21(2): 183-198.

[4] Baden-Fuller, C., Morgan, M. Business Models as Models. Long Range Planning, 2010, 43 (2-3): 156-171.

[5] Casadesus - Masanell, R., Ricart, J.E. From Strategy to Business Models and onto Tactics. Long Range Planning, 2010, 43 (2-3): 195-215.

[6] Teece, D. J. Business Models, Business Strategy and Innovation. Long Range Planning, 2010,43 ( 2-3) : 172-194.

[7] Osterwalder, A., Yves Pigneur, Chirstopher L. Tucci, Clarifying Business Models: Origins, Present, and Future of the Concept.Communications of the Information Systems, 2005, 15 (5):1-25

[8] Wang Yingluo. System engineering. Beijing: The magazine of Mechanical Industry 4 edition, 2011. 6-9. 